\title{
Lychnothamnus barbatus (Meyen) Leonh. - rediscovered in shalow Lake Šventininkai (Lithuania) after 50 years
}

\author{
Zofija Sinkevičiené ${ }^{1} \&$ Neringa Urbaitè-Maževič̌ ${ }^{2}$
}

${ }^{1}$ Nature Research Centre, Institute of Botany, Žaliụjų ežerụ Str. 49, LT-08406 Vilnius, Lithuania, e-mail: zofija.sinkeviciene@botanika.lt ${ }^{2}$ Lithuanian Educological University, Studentu Str. 39, LT-08106, Vilnius, Lithuania, e-mail: numazevic@gmail.com

\begin{abstract}
Lychnothamnus barbatus, which in Lithuania occurs northernmost in Europe, was identified in 4 lakes: Balsys, Mažasis Gulbinų, Vygris and Šventininkai. The aim of the paper was to present the recent vegetation, habitat conditions, abundance and co-occurring plant species in shallow Lake Šventininkai. L. barbatus population was rediscovered after 50 years. It was recorded in 1823 and 1960, but it has not been detected later on during scattered investigations until now. Recent vegetation of Lake Šventininkai is a typical of eutrophic lakes with the domination of Ceratophyllum demersum, Elodea canadensis and rarely - L. barbatus. The submerged communities are represented by 7 associations. L. barbatus was distributed at the depth of 1.1-2.1 m. Nitellopsis obtusa, Chara globularis, Chara contraria were the most common, co-occurring species of L. barbatus. Lake Šventininkai is a unique, very shallow (average depth $<3 \mathrm{~m}$ ) lake with re-established $L$. barbatus population after its total decline in strongly polluted lake waters following the lake's self-purification. The presented data are important for the restoration of the status of the protected area and management of this territory.
\end{abstract}

Key words: charophytes, Lychnothamnus barbatus, Chara, lakes, population, re-establishement, conservation

\section{Introduction}

Lychnothamnus barbatus is one of the rarest charophyte species in the world. Its distribution in Europe, Asia and Australia was comprehensively described by Sugier et al. (2010). Over the past decade, it was investigated mostly in Australia (Casanova et al. 2003; Garcia 2003), Balkans (Blaženčić \& Blaženčić 2003), Poland (Pełechaty \& Pukacz 2006; Pełechaty et al. 2009; Kolada 2009; Gąbka et al. 2010) and Lithuania (Balevičius 2001; Sinkevičienè 2009). The decline of this species, especially distinctive at the end of the $20^{\text {th }}$ century (Krause 1997; Casanova et al. 2003; Blaženčić et al. 2006), was also noted in Polish and Lithuanian populations (Balevičius 2001; Siemińska et al. 2006; Sinkevičienè 2007; Pełechaty et al. 2009). Poland and Lithuania, situated at the northern limit of L. barbatus distribution, are exceptional in Europe, because more or less stable populations were known there since the $19^{\text {th }}$ century (Balevičius 2001; Sinkevičiene 2007; Gąbka et al. 2010; Sugier et al. 2010).

L. barbatus, in Lithuania occurring northernmost in Europe, had been recorded in five lakes: Balsys, Gulbinai, Vygris, Šventinkai and Sągardas (Šarkinienè
\& Trainauskaitė 1978). However, one locality - in Lake Sagardas (eastern part of the country) - has never been confirmed by herbarium specimens or recent findings and is doubtful. Ten years ago, the occurrence of $L$. barbatus was confirmed for two lakes (Balevičius 2001). In summer of 2011, the species was found in additional two lakes. Hence, at the present time $L$. barbatus in Lithuania occurs in 4 lakes: Balsys, Mažasis Gulbinų, Vygris and Šventininkai.

Lake Šventininkai, most probably, is the oldest known locality of $L$. barbatus in Europe, first recorded at the beginning of the $19^{\text {th }}$ century. Wolfgang (1824) announced in local press about a new, undescribed Chara species (species nova) discovered in Lake Šventininkai by a student $\mathrm{S}$. Gorski. The collection consisting of 42 herbarium sheets under the name Chara radiata 'mihi' gathered in this lake is deposited at the Herbarium of Vilnius University (WI) together with other charophyte specimens collected by S. B. Gorski (Minkevičius \& Trainauskaite 1970). However, the new species under the name Chara radiata was not described and published validly. By mistake, Gorski (1830) himself reported Chara brachiata Dierb. instead of Chara radiata. After more than one hundred years, 
Chara radiata herbarium specimens were re-determined as L. barbatus by Mowszowicz (1947). The species was last recorded in Lake Šventininkai in 1960 (Šarkinienè 1961). According to unpublished reports and personal communications, the species had never been found there until now. Šventininkai Botanical Reserve, which was established in 1960 for the protection of this rare species, was removed from the lists of protected areas in 1988.

The aim of the investigations was to verify the recent vegetation in Lake Šventininkai. The rediscovery of $L$. barbatus after 50 years was a great surprise and enabled scientists to ascertain the recent vegetation, the conditions of growth and co-occurring species of this exceptional Charophyte. The obtained data may be interesting and important because it is the first known spontaneous re-establishment of L. barbatus in European lakes.

\section{Materials and methods}

The study was performed in Lake Šventininkai $\left(54^{\circ}\right.$ $35^{\prime} 12.51^{\prime \prime}, 25^{\circ} 03^{\prime} 23.56^{\prime \prime}$ WGS) (Fig. 1). It is located on the outwash plane formed during the late Nemunas (Weichselian) glaciation (Guobyte \& Satkūnas 2011). Urban-agrarian landscape dominates in the catchment area.

Since the data on the morphological, physical or hydrochemical parameters of the lake had never been studied, some characteristics were determined during field investigations in August (Table 1).

Table 1. Basic habitat properties of Lake Šventininkai

\begin{tabular}{lrr}
\hline Property & Unit & Value \\
\hline Area & ha & 15.5 \\
Max. depth & $\mathrm{m}$ & 3.5 \\
Secchi depth & $\mathrm{m}$ & 3.5 \\
$\mathrm{pH}$ & & 7.57 \\
Conductivity & $\mu \mathrm{S} / \mathrm{cm}$ & 143 \\
Total hardness & $\mathrm{meq} / \mathrm{l}$ & 1.7 \\
$\mathrm{Ca}^{2+}$ & $\mathrm{mg} / \mathrm{l}$ & 25.8 \\
$\mathrm{Mg}^{2+}$ & $\mathrm{mg} / \mathrm{l}$ & 5.0 \\
Total N & $\mathrm{mg} / \mathrm{l}$ & 2.8 \\
Total P & $\mathrm{mg} / \mathrm{l}$ & 0.03 \\
\hline
\end{tabular}

Maximal depth was measured using portable metre, transparency - with Secchi disk. Water $\mathrm{pH}$ and conductivity were measured in situ using portable universal meter MultiLine F/Set-3. The sample of surface water from the deepest site was taken in a plastic container, put in the fridge and transported to laboratory. The sample analysis was performed by the certified laboratory "Vandens tyrimai" following standard methods (cations - LST EN ISO 14911, anions - LST EN ISO 10304). Trophic level was determined according to limits for Secchi depth, total nitrogen and total phosphorus (Håkanson 1980).

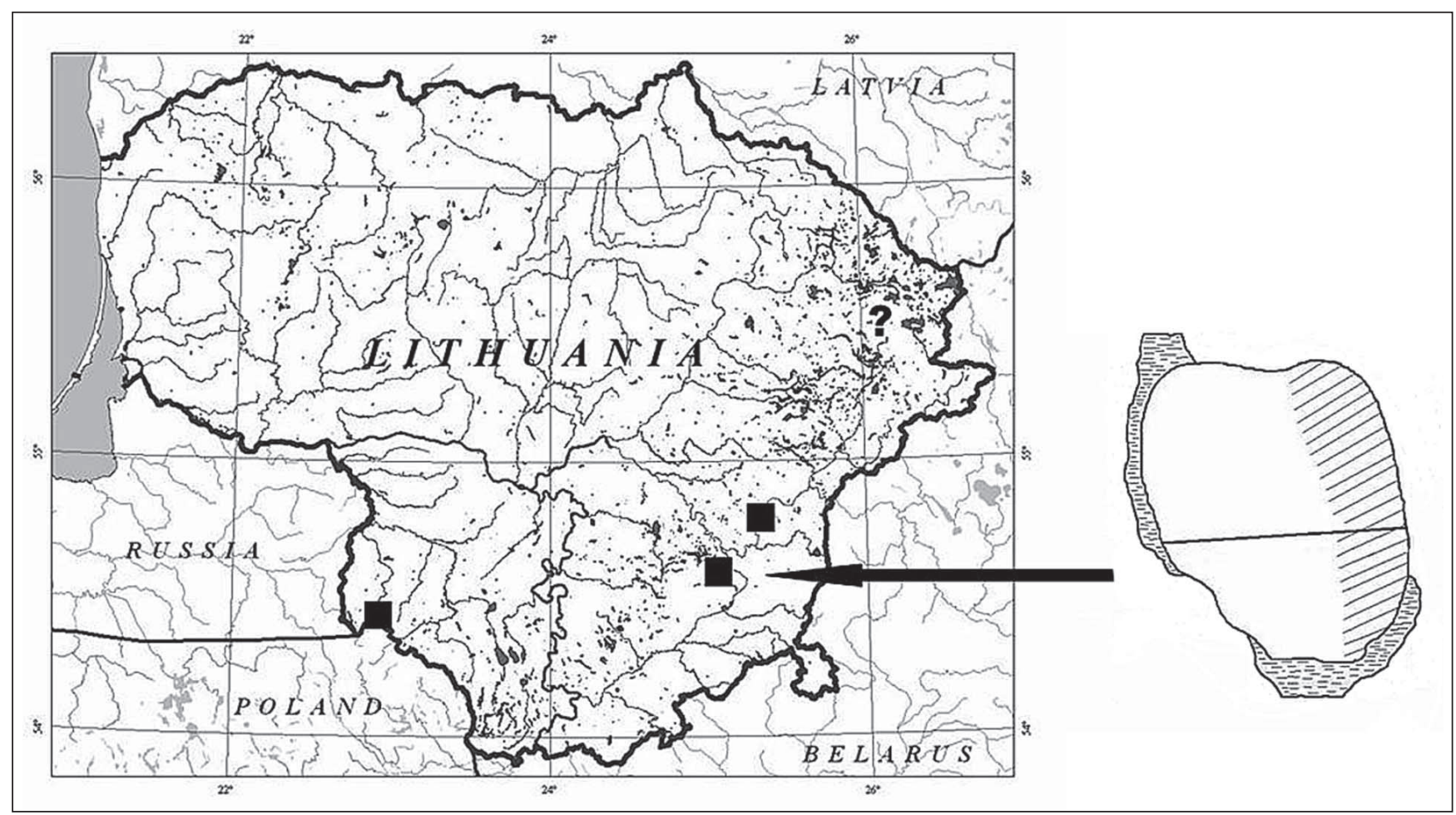

Fig. 1. Location of Lake Šventininkai in Lithuania and position of transect in the lake Explanations: - - localities of Lychnothamnus barbatus, confirmed in 2011, ? - doubtful locality, _ - E-W transect through the Lake Šventininkai, /III/ area occupied by charophytes 
The survey of flora and vegetation, with special attention paid to hydrophytes, was performed in 6 transects from a boat and using a hook and an aquascope. To identify the diversity of macrophyte communities, the method of phytosociological relevés (BraunBlanquet 1964) was applied. Species composition, abundance of each species and total plant cover layer in each representative sampled patch were determined.

In representative part of the lake, species diversity, abundance and distribution along depth gradient were determined in E-W belt transect $\pm 10 \mathrm{~m}$ in width (Fig. 1). Initially, species inventory was performed in depth zones of each $0.5 \mathrm{~m}$, subsequently depth limits were corrected according to ranges of dominating species patches. In shallow sites, ranges of the patches were determined by eye or using the aquascope, in the deepest locations - by the hook samples only. Species composition and abundance (according to Braun-Blanquet scale) in narrow patches were determined by the threehook samples, and in large patches - taking at least five random samples.

Charophyta species were identified using keys by Gollerbach \& Krasavina (1983) and Krause (1997). Nomenclature and authors for charophytes followed Blümel (2003), and for vascular plants - Gudžinskas (1999).

\section{Results}

There are scarce data concerning earlier macrophyte vegetation and L. barbatus in Lake Šventininkai. The herbarium collection of L. barbatus by S. B. Gorski is the only evidence of its high abundance in 1823 (Wolfgang 1824; Mowszowicz 1947; Minkevičius \& Trainauskaite 1970). Most probably, this species must have been absolutely dominant in the lake, since other charophytes or vascular plant species were not mentioned or deposited at the above-mentioned herbarium or any other herbaria.

In 1960, the species was reported growing very abundantly in the south-western part of the lake (Šarkinienè 1961). At that time, six species co-occurring with $L$. barbatus were mentioned: Nitellopsis obtusa, Chara globularis, Elodea canadensis, Myriophyllum spicatum L., Stratiotes aloides L., Fontinalis antipyretica Hedw. (Balevičius 2001). The finding of L. barbatus in formerly known locality in 1960 was the basis to establish the protected area called "Šventininkai Botanical Reserve".

The information about the vegetation in Lake Šventininkai after 1960s is also very scarce and based on unpublished data of sporadic research or personal observations. About 1987, a complete degradation of submerged vegetation was observed by Balevičiené (personal communication). As a result of the reported absence of $L$. barbatus, Šventininkai Botanical Reserve was struck off from the list of protected areas in 1988. The first signs of a recovery of hydrophytes were observed in 2001 (Balevičienè, personal communication). During the investigation in 2003, eight submerged plant species (Chara hispida (L.) Hartm., C. demersum, Batrachium circinatum (Sibth.) Spach, Drepanocladus sp., Elodea canadensis, Lemna trisulca L., Potamogeton natans L., Potamogeton perfoliatus L.) were recorded, but only the association of Ceratophylletum demersi Hild 1956 in submerged vegetation, Phragmitetum australis (Gams 1927) Schmale 1939 and Equisetetum limosi Steffen 1931 - in helophytes belt were mentioned (Stepanavičienè 2003, unpublished data). At least in the period from 1987-2003, Lychnothamnus barbatus in Lake Šventininkai was not observed. The real time of the species disappearance in the period 1960-1987 and its reappearance in the period 2003-2011 remains unknown.

At present, the vegetation covers almost the entire bottom of Lake Šventininkai. The total of 21 species of hydrophytes and 18 species of helophytes was inventoried. Communities of submerged plants prevailing in the lake represented 4 associations of Charophytes (Charetum contrariae Corillion 1957, Charetum fragilis Fijałkowski 1960, Lychnothamnetum barbati (Gołdyn 1984) Brzeg et M. Wojterska 2001, Nitellopsidetum obtusae (Sauer 1937) Dąmbska 1961) and 3 associations of vascular plants (Ceratophylletum demersi, Elodeetum canadensis Egler 1973 and Potamogetonetum lucentis Hueck 1931). Submerged plant species were important components in two communities of helophytes - Equisetetum limosi and Eleocharitetum palustris Schennikow 1919. Equisetetum limosi was most common in the lake, other communities of helophytes were scattered or present in certain parts.

L. barbatus occurred mainly in the eastern part of the lake. Charophytes occupied about one third of its area, while the communities of submerged vascular plants prevailed in the remaining part (Fig. 1). Lychnothamnetum barbati (Table 2, relevés 1-4) was distributed at the depth of 1.1-2.1 m. Lychnothamnus did not form completely monospecific communities usually it dominated in the upper layer and accompanying species Chara contraria, Chara globularis or Nitellopsis obtusa formed the lower layer. Floristic richness of phytocoenoses was low and ranged from 2 to 5 species. Nitellopsis obtusa was the most consistent accompanying species of $L$. barbatus. The transitional communities between Lychnothamnetum barbati and Nitellopsidetum obtusae with equally abundant codominated species (Table 3, relevé 4) were distributed at the depth of 1.5-2.1 m. Outside its own communities, L. barbatus often occurred within the Nitellopsidetum obtusae (Table 2, relevés 5-6), rarely was observed in Elodeetum canadensis (Table 2, relevés 89), very rarely - within Charetum fragilis (Table 2, 
Table 2. Species composition of the communities with Lychnothamnus barbatus in Lake Šventininkai

\begin{tabular}{|c|c|c|c|c|c|c|c|c|c|c|}
\hline Number of relevés & 1 & 2 & 3 & 4 & 5 & 6 & 7 & 8 & 9 & 10 \\
\hline Date & $\begin{array}{c}12.08 . \\
2011\end{array}$ & $\begin{array}{c}12.08 . \\
2011\end{array}$ & $\begin{array}{c}19.08 . \\
2011\end{array}$ & $\begin{array}{c}19.08 . \\
2011\end{array}$ & $\begin{array}{c}12.08 . \\
2011\end{array}$ & $\begin{array}{c}19.08 . \\
2011\end{array}$ & $\begin{array}{c}12.08 . \\
2011\end{array}$ & $\begin{array}{c}12.08 \\
2011\end{array}$ & $\begin{array}{c}19.08 . \\
2011\end{array}$ & $\begin{array}{c}19.08 . \\
2011\end{array}$ \\
\hline Depth (m) & 2.0 & 2.0 & $1.1-1.5$ & $1.5-2.1$ & 1.5 & 1.1 & 1.5 & $1.0-1.1$ & 2.1 & 3.1 \\
\hline Cover $\%$ & 100 & 100 & 100 & 100 & 100 & 100 & 100 & 100 & 100 & 100 \\
\hline Number of species in relevé & 3 & 2 & 5 & 2 & 6 & 5 & 6 & 7 & 4 & 3 \\
\hline $\begin{array}{l}\text { Lychnothamnus barbatus } \\
\text { Ch. C. Charetea }\end{array}$ & 5 & 5 & 4 & 3 & 1 & 1 & 1 & 2 & 1 & + \\
\hline Nitellopsis obtusa & 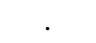 & 1 & 2 & 3 & 5 & 4 & 1 & 1 & . & . \\
\hline Chara globularis & 2 & . & 1 & . & 1 & 3 & 4 & . & . & . \\
\hline $\begin{array}{l}\text { Chara contraria } \\
\text { Ch. C. Potamogetonetea }\end{array}$ & 2 & . & 1 & . & . & 2 & 1 & . & . & . \\
\hline Elodea canadensis & . & . & 1 & . & 1 & . & 1 & 3 & 4 & . \\
\hline Ceratophyllum demersum & . & . & . & . & & . & + & 1 & 3 & 5 \\
\hline Batrachium circinatum & . & . & . & . & 1 & . & . & . & & . \\
\hline $\begin{array}{l}\text { Myriophyllum spicatum } \\
\text { Others }\end{array}$ & . & . & . & . & & . & . & . & 1 & . \\
\hline Drepanocladus aduncus & . & . & 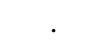 & . & 1 & 2 & . & 3 & . & . \\
\hline Fontinalis hypnoides & . & . & & . & . & . & . & 1 & . & . \\
\hline Equisetum fluviatile & 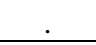 & . & & 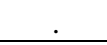 & 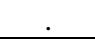 & . & . & 2 & . & . \\
\hline
\end{tabular}

Explanations: Syntaxonomical units: relevés 1-4 - Lychnothamnetum barbati, relevés 5-6 - Nitellopsidetum obtusae, relevé 7 - Charetum fragilis, relevés 8-9 - Elodeetum canadensis, relevé 10 - Ceratophylletum demersi

relevé 7) or Ceratophylletum demersi (Table 2, relevé 10). In total, 10 species co-occurring with L. barbatus were registered (three charophytes, two bryophytes and five magnoliophytes). L. barbatus was fertile in the whole distribution zone.

The distribution of species under depth gradient is presented in E-W transect (Table 3). The patches of dominant species changed almost every $0.5 \pm 0.1 \mathrm{~m}$. The unvegetated zone situated at the depth of 3.1-3.5 m was very small. In the eastern part, charophytes were distributed at the depth of $0.0-2.5 \mathrm{~m}$, but optimal conditions for the development of entire stands was be- tween 0.5 and $2.1 \mathrm{~m}$. Chara contraria was most abundant in the shallowest part, Nitellopsis obtusa - in the deepest part and L. barbatus dominated in the intermediate depth zone. The abundance of Chara globularis was low in the whole distribution zone. $C$. demersum dominated in the large middle part at the depth of 2.5$3.1 \mathrm{~m}$, while Elodea canadensis bordered it on the shallowest sites. This species was also abundant in the domination zone of Equisetum fluviatile in western part of transect. 15 species of hydrophytes and 15 species of helophytes recorded in the transect made up $77 \%$ of the total number of species (39) inventoried in the lake.

Table 3. Species distribution and abundance along E-W transect through the Lake Šventininkai

\begin{tabular}{|c|c|c|c|c|c|c|c|c|c|c|c|}
\hline \multirow{2}{*}{$\begin{array}{l}\text { Species } \\
\text { Eleocharis palustris }\end{array}$} & \multicolumn{11}{|c|}{ Abundance } \\
\hline & 3 & 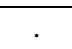 & 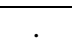 & $\cdot$ & 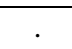 & . & . & r & $\cdot$ & . & \\
\hline Equisetum fluviatile & . & . & . & . & . & . & . & . & . & . & 4 \\
\hline Hydrocharis morsus-ranae & 2 & . & . & . & . & . & . & . & . & . & . \\
\hline Persicaria amphibia & 1 & . & . & . & . & . & . & . & . & . & . \\
\hline Fontinalis hypnoides & 1 & . & . & . & . & . & . & . & . & . & . \\
\hline Drepanocladus aduncus & 1 & 1 & 1 & 1 & . & 2 & . & . & . & . & . \\
\hline Chara globularis & 1 & 2 & 2 & 1 & $\dot{1}$ & . & . & . & . & . & . \\
\hline Chara contraria & 1 & 3 & 2 & 1 & . & . & . & . & . & . & . \\
\hline Nitellopsis obtusa & . & 2 & 3 & 3 & $i$ & . & . & $i$ & . & . & . \\
\hline Lychnothamnus barbatus & . & . & 5 & 3 & 1 & . & . & 1 & . & . & . \\
\hline Ceratophyllum demersum & 2 & 1 & . & . & 3 & 5 & . & 5 & 4 & 1 & 2 \\
\hline Elodea canadensis & 1 & 1 & $\dot{1}$ & $\dot{1}$ & 4 & 2 & . & 1 & 3 & 5 & 3 \\
\hline Myriophyllum sp. & 2 & . & . & . & 1 & 1 & . & . & . & 1 & 1 \\
\hline Lemna trisulca & . & . & . & . & . & 1 & . & . & $\dot{1}$ & 2 & 2 \\
\hline Potamogeton pectinatus & . & 1 & . & . & . & . & . & . & . & . & . \\
\hline Batrachium circinatum & . & . & . & . & . & . & . & . & . & 1 & . \\
\hline Potamogeton lucens & 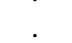 & & . & . & . & . & 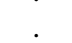 & . & . & . & 1 \\
\hline Length of zone (m) & 10 & 20 & & & 10 & 40 & 10 & & & 80 & 30 \\
\hline Depth $(\mathrm{m})$ & $\begin{array}{l}0.0- \\
0.5\end{array}$ & $0,5-$ & $\begin{array}{l}1.1- \\
1.5\end{array}$ & $\begin{array}{l}1.5- \\
2.1\end{array}$ & $\begin{array}{l}2.1- \\
2.5\end{array}$ & $\begin{array}{l}2.5- \\
3.1\end{array}$ & $\begin{array}{l}3.1- \\
3.5\end{array}$ & $\begin{array}{l}3.1- \\
3.0\end{array}$ & $3.0-$ & $2.5-$ & 1.0 \\
\hline
\end{tabular}

Sporadic helophyte species recorded in the E part at the depth of 0.0-0.5 m: Acorus calamus, Alisma plantago aquatica, Bidens cernua, Calla palustris, Cicuta virosa, Epilobium palustre, Lycopus europaeus, Phragmites australis, Rorippa palustris, Scutellaria galericulata, Typha angustifolia, Typha latifolia and Veronica beccabunga 


\section{Discussion}

The decline of L. barbatus noted in Australian and European populations at the end of the $20^{\text {th }}$ century was, in many cases, related with human activity, which caused the deterioration of water quality and habitat modification (Casanova et al. 2003; Gąbka et al. 2010). The period of its disappearance in most localities in Poland between 1970-1990 (Gąbka et al. 2010) coincided with the possible time of species extinction in Lake Šventininkai. In the second half of the $20^{\text {th }}$ century, the catchment area of the lake was used for agriculture. Most probably, the intensive farming along the shores was main pollution source of the small and shallow lake. This activity was finished in about 1992. Recently, the lake has been used for recreational purposes and fishing. We did not find any information concerning earlier condition of the lake water. According to recent data, the water in Lake Šventininkai is slightly alkaline, moderately hard and transparent up to the bottom. With maximal depth of $3.5 \mathrm{~m}$, this lake is unique among deep Lithuanian Lychnothamnus-lakes. In addition, it is distinguished from other northern Lychnothamnus-lakes by significantly lower hardness of water. Total water hardness, conductivity and calcium ion concentrations are two or more times lower, whereas total nitrogen concentration and water transparency are the highest in comparison with other Lychnothamnus-lakes in Lithuania (Balevičius 2001). Furthermore, the values of conductivity and calcium ion concentrations in Lake Šventininkai are about two times lower than the minimal values estimated for Polish lakes (Gąbka et al. 2010). According to Secchi, the depth and concentration of total phosphorus in Lake Šventininkai belongs to eutrofic, while the concentration of total nitrogen corresponds to that of hypertrophic lakes (Håkanson 1980).

Recent vegetation in Lake Šventininkai is typical for waters rich in nutrients. Due to the high water transparency, L. barbatus can be distributed in a larger area of the lake, but the possibly suitable sites for this species are occupied by $C$. demersum and Elodea canadensis. C. demersum considered as an indicator of eutrophic waters, is the main competitor and important component of vegetation in the lakes with $L$. barbatus as well as in the lakes, where it is extinct (Pelechaty et al. 2009; Gąbka et al. 2010). This species was recorded as dominant or co-dominant with Lychnothamnus barbatus in many Polish lakes (Pełechaty et al. 2009). In Lithuania, $C$. demersum was reported as a co-dominant species only in Lake Vygris (Balevičius 2001), situated in agricultural landscape, too.

Elodea canadensis, another very common species in Lake Šventininkai, also could be an important competitor of $L$. barbatus. This species was recorded as an accompanying species in the communities of $L$. barbatus in Poland and Lithuania, but was neither very abundant nor constant (Balevičius 2001; Gąbka et al. 2010). The intervention of Elodea canadensis in usually dense stands of charophytes is complicated, but it successfully occupies damaged habitats or communities (Sinkevičienè 2010).

Nitellopsis obtusa, co-occurring with L. barbatus in Lake Šventininkai, is a common component of recent vegetation in Lychnothamnus-lakes in Lithuania (Balevičius 2001; Sinkevičienè 2010) and Poland (Pełechaty et al. 2009; Gąbka et al. 2010). Chara globularis and Chara contraria, quite constant in Lake Šventininkai, occur relatively rarely together with $L$. barbatus in other Lychnothamnus-lakes (Balevičius 2001; Gąbka et al. 2010).

As L. barbatus was not found in Lake Šventininkai, at least in the period between 1987-2003, it might be considered that the initial population was completely extinct. It is most likely that population recovered from the oospore bank preserved in the sediments (Bonis \& Grillas 2002). The survival of at least some individuals or spreading by birds is possible, but unlikely. As far as we know, it is the first case of spontaneous re-establishment of L. barbatus in European lakes after total extinction. According to Casanova et al. (2003), the oospores of $L$. barbatus are not abundant in propagule banks of Australian populations. The propagule banks of Lithuanian populations have never been studied, but, as we know, plants are usually fertile especially in shallow sites or clear water conditions, thus oospore banks possibly could be formed.

\section{Conclusions}

Recent vegetation of Lake Šventininkai is typical for eutrophic waters with dominant $C$. demersum, Elodea canadensis and, as exception, L. barbatus and its communities.

Domination of rare and sensitive charophyte species such as L. barbatus in Lake Šventininkai after strong pollution and total decline of the initial population is a unique situation and requires more detailed investigations.

The re-establishment of the population of $L$. barbatus can be related with the occurrence of a propagule bank, but also with currently unknown high capability of the lake for self-purification.

The fact of the occurrence of this globally rare and endangered charophyte species in Lake Šventininkai costitutes the basis for the restoration of its status as a protected area. Permanent monitoring of water quality and vegetation as well as management of this territory is necessary to allow the favourable status of L. barbatus. 


\section{References}

BALEviČIUS A. 2001. Distribution of Lychnothamnus barbatus community in Lithuania. Biologija 2:70-73.

BlažEnČIĆ J. \& BlažEnČIĆ Ž. 2003. An overview of the existing data on living Charophytes (Charales) of the Balkan Peninsula. Acta Micropalentol. Sin. 20(2): 103-110.

Blaženčić J., Stevanović B., Blaženčic Ž. \& Stevanovič V. 2006. Red Data List of Charophytes in the Balkans. Biodivers. Conserv. 15: 3445-3457.

BLÜMel C. 2003. Taxonomy and nomenclature. In: H. Shubert \& I. Blindow (eds.). Charophytes of the Baltic Sea, pp 261-284. A.R.G. Gantner Verlag Kommanditgesellschaft FL 9491 Ruggell.

Bonis A. \& Grillas P. 2002. Deposition, germination and spatio-temporal patterns of charophyte propagule banks: a review. Aquatic Botany 72(3-4): 235-248.

Braun-Blanquet J. 1964. Pflanzensoziologie. Grundzüge der Vegetationskunde. 865 pp. Springer Verlag, Wien.

Casanova M. T., Garcia A \& Feist M. 2003. The ecology and conservation of Lychnothamnus barbatus. Acta Micropalentol. Sin. 20: 118-128.

GąbKa M., Owsianny P. M. \& Burchardt L. 2010. The influence of co-occuring vegetation and habitat variables on distribution of rare charophyte species Lychnothamnus barbatus (Meyen) in lakes of western Poland. Pol. J. Ecol. 58(1): 13-25.

Garcia M. 2003. Lychnothamnus barbatus (Meyen) Leonhardi from Australia: statistical analysis of its gyrogonite and comparison with European collections. Acta Micropalentol. Sin. 20: 111-117.

Gollerbach M. \& Krasavina L. 1983. Opredelitel' presnovodnykh vodoroslej SSSR. Kharovyje vodorosli - Charophyta, 14, 190 pp. Nauka, Leningrad.

Gorski S. B. 1830. Botanische Bemerkungen. In: E. EichwALD (ed.). Naturhistorische Skizze von Lithauen, Volhynien und Podolien in geognostisch-mineralogischer, botanischer und zoologischer Hinsicht, pp. 105-180. Gedruckt bei Joseph Zawadzki, Wilno.

Guobytë R. \& SAtkúnAs J. 2011. Pleistocene glaciations in Lithuania. In: J. Ehlers, P. L. GibBARd \& P. D. Hughes (eds.). Developments in Quarternary Science, 15: 231246.

GuDŽINSKAS Z. 1999. Lietuvos induočiai augalai. 211 pp. Botanikos instituto leidykla, Vilnius.

HÅKANSON L. 1980. An ecological risk index for aquatic pollution control - a sedimentological approach. Water Research 14: 995-1001.

KoladA A. 2009. Is the Lychnothamnus barbatus (Meyen) Leonhardi 1963 a good indicator of water quality? A new location of the species in Gorskie Lake near Gostynin (Central Poland). Oceanological and Hydrobiological Studies 38(2): 39-43.
Krause W. 1997. Charales (Charophyceae). In: H. Ettl, G. Gartner, H. Heynig \& D. Molenhauer (eds.). Süsswasserflora von Mitteleuropa, 18, 202 pp. Gustav Fischer, Jena, Studtgart, Lubeck, Ulm.

Minkevičius A. \& Trainauskaitė I. 1970. S. Gorskio maurabragainiu (Charophyta) rinkinys Vilniaus Valstybiniame V. Kapsuko vardo universitete. Biologija 10: 5-13.

Mowszowicz J. 1947. Characeae Wilna i jego okolic Acta Soc. Bot. Pol. 18(2): 1-8.

Pelechaty M. \& Pukacz A. 2006. Charophytes species and communities of different types of water ecosystems of the Ziemia Lubuska region (Western Poland). Biodv. Res. Conserv. 1-2: 138-142.

Pęechaty M., GąbKa M., Sugier P., Pukacz A., Chmiel S., Ciecierska H., Kolada A. \& Owsianny P. M. 2009. Lychnothamnus barbatus in Poland: habitats and associations. - Charophytes 2(1): 13-18.

Siemińska J., Bąk M., Dziedzic J., GąbKa M., Gregorowicz P., Mrozińska T., Pelechaty M., Owsianny P. M., Pliński M. \& Witkowski A. 2006. Red list the algae in Poland. In: Z. MireK, K. Zarzycki, W. WoJeWOdA \& Z. Szeląg (eds.). Red list of plants and fungi in Poland, pp. 35-52. W. Szafer Institute of Botany, Polish Academy of Sciences, Kraków.

SINKEVIČIENĖ Z. 2007. Šiurpinis žvakidumblis Lychnothamnus barbatus (Meyen) Leonh. In: V. Rašomavičıus (ed.). Red Data Book of Lithuania, pp. 285. Vilnius.

SinKEVIČIENĖ Z. 2009. Morphological variation in Lychnothamnus barbatus (Meyen) Leonh. in Lake Balsys (Lithuania). Charophytes 2(1): 25-30.

SINKEVIČIENĖ Z. 2010. Elodea canadensis L. v estestvennykh vodojomakh Litvy. (Elodea canadensis in natural waters in Lithuania). Proceedings of the I(VII) International conference on aquatic macrophytes "Hydrobotany 2010", pp. 275-276. Yaroslavl, "Print House".

Sugier P., Peeechaty M., Gąbka M., Owsianny P. M., Pukacz A., Ciecierska H. \& Kolada A. 2010. Lychnothamnus barbatus: global history and distribution in Poland. Charophytes 2(1): 19-24.

ŠARKINIENĖ I. 1961. Rytụ ir Pietụ Lietuvos TSR ežerų makrofitu floristinè, geografinè ir morfo-ekologinè analizè. Biologija 1: 159-194.

ŠArkiniEnĖ I. \& TrainAUSKaitė I. 1978. Retieji ir globotini Lietuvos TSR augalai. (Rare and protected aquatic plants in Lithuania). In: V. ButKus (ed.). Augalai ir žmogus, pp. 52-57. Mokslas, Vilnius.

Wolfgang J. F. 1824. Wiadomość o nowo przybyłych roślinach do Flory Litewskiey w r. 1822 i 1823. Dziennik medycyny, chirurgii i farmacji 2(4): 647-656. 